\title{
Magnetic petrology of high Fe-Ti eclogites from the CCSD main hole: Implications for subduction-zone magnetism
}

\author{
Qingsheng Liu, ${ }^{1}$ B. Ronald Frost ${ }^{2}$ Hongcai Wang, ${ }^{3}$ Jianping Zheng, ${ }^{4}$ Qingli Zeng, ${ }^{1}$ \\ and Zhenmin $\mathrm{Jin}^{4}$ \\ Received 24 June 2011; revised 29 May 2012; accepted 30 May 2012; published 20 July 2012.
}

[1] The high Fe-Ti eclogites with exsolved lamellar in 530-600 $\mathrm{m}$ depths from the Chinese Continental Scientific Drilling (CCSD) main hole in the Sulu Ultra-High Pressure (UHP) metamorphic belt, eastern China, record an anomalously high susceptibility $(\kappa)$, natural remanent magnetization (NRM) and Köenigsberger ratio Q $\left(N R M / J_{i}, J_{i}\right.$ is induced magnetization). This provides us with a good opportunity to study the effects of magnetic minerals and exsolution lamellae on the magnetic properties of deep rocks. In this paper, we have measured systematically magnetic properties and mineral assemblage and structure for three special samples (No. 83, No.86 and No.89). Results show that these Fe-Ti-rich eclogites are the result of the fine-grained (titano)-magnetite exsolution in pyroxene and lamellar structure consisting of finely interlayered ilmenite and hematite in exsolved hemo-ilmenite. We found that the dominant Fe-bearing oxide minerals in samples studied are ilmenite, hematite (Hem + Ilm up to $25 \%$ ), little (titano)magnetite and pyrite. The ferromagnetic susceptibility is mainly controlled by fine grained (titano)magnetite and NRM is closely related to the exsolved lamellar structure. We hence propose that the anomalous magnetism of these eclogites observed in our samples is the result of exsolution from homogenous pyroxene and ilmeno-hematite during cooling and decompression processes. These Fe-Ti-rich eclogites might be one of the sources of high-magnetic anomalies observed in the Sulu subduction zone, eastern China.

Citation: Liu, Q., B. R. Frost, H. Wang, J. Zheng, Q. Zeng, and Z. Jin (2012), Magnetic petrology of high Fe-Ti eclogites from the CCSD main hole: Implications for subduction-zone magnetism, J. Geophys. Res., 117, B07102, doi:10.1029/2011JB008621.

\section{Introduction}

[2] The magnetic properties of deep crustal rocks are mainly controlled by minerals of the magnetite - ulvöspinel $\left(\mathrm{xFe}_{2}^{2+} \mathrm{Ti}^{4+} \mathrm{O}_{4} \cdot(1-\mathrm{x}) \mathrm{Fe}^{3+}\left(\mathrm{Fe}^{2+} \mathrm{Fe}^{3+}\right) \mathrm{O}_{4}\right)$, hematite - ilmenite $\left(\mathrm{xFe}^{2+} \mathrm{Ti}^{4+} \mathrm{O}_{3} .(1-\mathrm{x}) \mathrm{Fe}_{2}^{3+} \mathrm{O}_{3}\right)$, and pyrrhotite $\left(\mathrm{Fe}_{1-\mathrm{X}} \mathrm{S}\right)$ solid solutions [Frost and Shive, 1986; Banerjee, 1991; Frost, 1991a, 1991b; Q. Liu et al., 2007, 2008, 2009]. However, the exact causes of the abundances of these minerals and how they relate to the magnetic signature of the continental lower crust and to long-wavelength magnetic anomalies (or lithosphere's magnetic field) are still poorly known [Shive et al., 1992; Wasilewski and Mayhew, 1992; McEnroe et al., 2004] because, in many regions, it is still difficult to identify the agents that cause these anomalies [Florio et al., 1993; Langel and Hinze, 1998; Blakely et al., 2005].

\footnotetext{
${ }^{1}$ Department of Geophysics, China University of Geosciences, Wuhan, China.

${ }^{2}$ Department of Geology and Geophysics, University of Wyoming, Laramie, Wyoming, USA.

${ }^{3}$ Institute of Geomechanics, CAGS, Beijing, China.

${ }^{4}$ Faculty of Earth Sciences, China University of Geosciences, Wuhan, China.

Corresponding author: Q. Liu, Department of Geophysics, China University of Geosciences, Wuhan 430074, China. (lqs321@cug.edu.cn)

Published in 2012 by the American Geophysical Union.
}

[3] From a large number of previous magnetic measurements of crustal rocks, it is known that the magnetite is the main source of magnetism in deep crustal rocks [Frost and Shive, 1986], but recently, the exsolved hematite-ilmenite solid solution has been shown to carry a strong and stable natural remanane magnetism (NRM) [McEnroe and Brown, 2000; McEnroe et al., 2001b; Kletetschka et al., 2002; Robinson et al., 2006; McEnroe et al., 2007, 2009]. The hematite and ilmenite in these rocks are interlayered with thicknesses ranging down to unit-cell scale (1-2 nm) [Robinson et al., 2002]. Two types of rocks have been found to carry this magnetic source: hematite - ilmenite ores [Robinson et al., 2002; Dyar et al., 2004; McEnroe et al., 2002, 2007] and relatively oxidized granulite-facies rocks [McEnroe and Brown, 2000; McEnroe et al., 2001a; Kletetschka et al., 2002; Kasama et al., 2004]. Robinson et al. [2002, 2004] have postulated that this type of NRM is caused by a 'contact layer' between antiferromagnetic hematite and ilmenite within the highly exsolved hemo-ilmenite or ilmeno-hematite and called it lamellar magnetism [Robinson et al., 2002; Kasama et al., 2004]. McCammon et al. [2009] have proposed a quantitative estimation of contact layer abundance by Mössbauer spectroscopy and evaluating lamellar magnetism. As a result of these pioneering works, it is now believed that, in addition to 


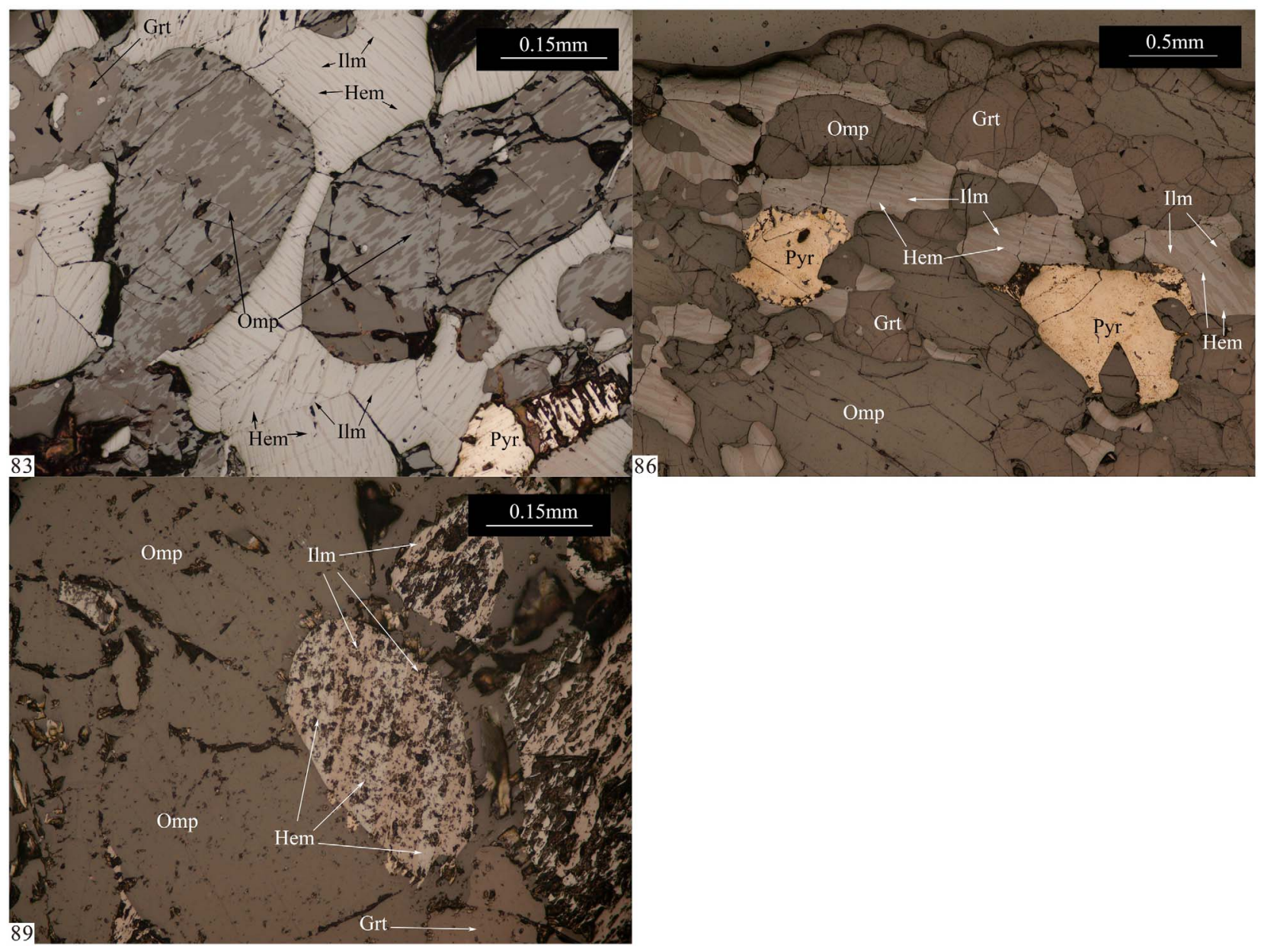

Figure 1. Reflected light photomicrographs of high-Fe-Ti eclogites with exsolved lamellae-rich mineral grains. Omp-ompacite; Gar-garnet; Pyr-pyrite; Ilm-ilmenite; Hem-hematite. Hemo-ilmenite intergrowth; the ilmenite-hematite solid solution has a very fine intergrowth structure.

titano-magnetite, exsolved hemo-ilmenite or ilmeno-hematite can produce intensively stable NRM which provides a new perspective for interpreting aeromagnetic anomalies [McEnroe and Brown, 2000; Kletetschka et al., 2002; McEnroe et al., 2009].

[4] In general, high and ultrahigh pressure (UHP) metamorphosed basic rocks do not exhibit an intense magnetism [Q. Liu et al., 2007, 2009; H. Xu et al., 2009] because Fe-Ti oxides are consumed at high pressures by solution of $\mathrm{Fe}^{3+}$ and Ti into garnet and clinopyroxene [Frost, 1991a]. For this reason, most eclogites are paramagnetic or weakly ferromagnetic. However, magnetic properties of variable retrogressed eclogites are related to the retrogressed process and the tectonic fabric [Abalos and Aranguren, 1998; Strada et al., 2006; Liu et al., 2009; H. Xu et al., 2009]. In this paper we study the magnetic Fe-Ti-rich eclogites collected from the CCSD main hole in the Sulu UHP metamorphic belt, eastern China. These rocks exhibit a very strong NRM and could help us understand the sources of magnetic anomalies in high-pressure regimes.

\section{Geological Background}

[5] The Sulu UHP metamorphic belt of eastern China was formed during Triassic collision between the North China and Yangtze cratons [Zhang et al., 2006; Z. Xu et al., 2009]. The peak UHP metamorphism (4-5 GPa, 800-900 ${ }^{\circ} \mathrm{C}$ ) has been observed when a continental slab was subducted to a depth of $\sim 150 \mathrm{~km}$ at $\sim 230 \mathrm{Ma}[Z$. Xu et al., 2009]. The UHP metamorphic assemblages were preserved because they were rapidly uplifted to the upper crust between 230-200 Ma [Z. Xu et al., 2009].

[6] The main hole of the CCSD project is located at the southern segment of the Sulu UHP metamorphic belt $\left(34^{\circ} 25^{\prime} \mathrm{N} / 118^{\circ} 40^{\prime} \mathrm{E}\right)$, about $17 \mathrm{~km}$ southwest from Donghai county [Z. Xu et al., 2009]. The UHP eclogites extracted from the CCSD main hole contain rich geochemical and petrofabric information [Qi et al., 2009; Wang et al., 2009; Z. Xu et al., 2009]. Most eclogites from the drill hole only contain minor amounts of Fe-Ti oxides and are paramagnetic [Liu et al., 2009; H. Xu et al., 2009]. The highly magnetic eclogites studied in this paper are located at a depth of 530 $600 \mathrm{~m}$. They are only weakly retrograded and are composed of omphacite, garnet, apatite, phengite and quartz [Zhang et al., 2006; Y. Liu et al., 2007]. Zhang et al. [2006] described these eclogites as "high Fe-Ti eclogites," a term that we also used in our samples [Zeng et al., 2009; $Y$. Liu et al., 2007]. The high Fe-Ti eclogites are characterized by $32.91-42.2 \%$ of $\mathrm{SiO}_{2}, 15.74-33.24 \%$ of $\mathrm{FeO}^{\mathrm{T}}$ 


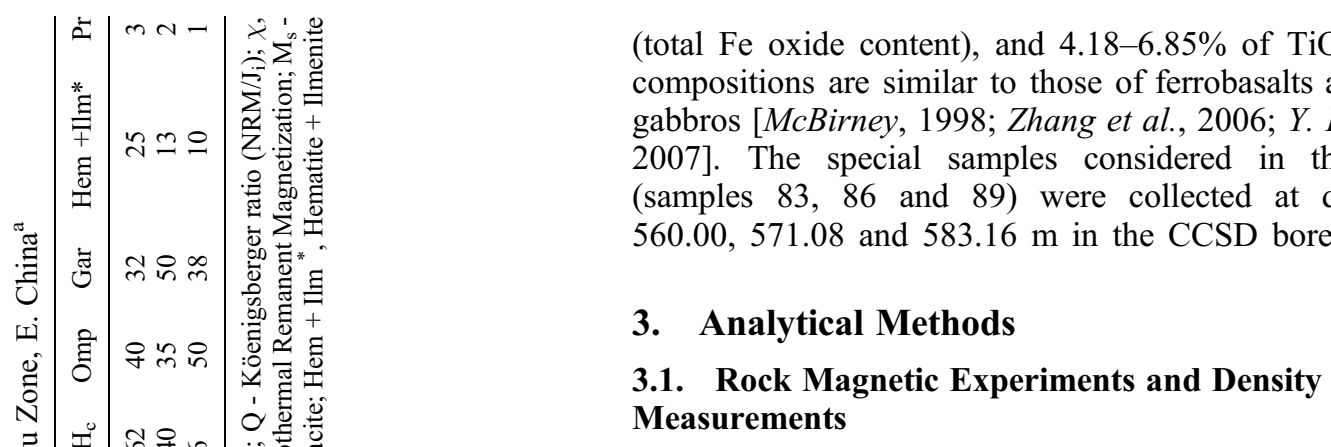

[7] The cylindrical samples were cut parallel to the borehole direction or perpendicular to foliation, with a diameter of $2.5 \mathrm{~cm}$ and height of $2.2 \mathrm{~cm}$. Low-field magnetic susceptibilities $(\kappa)$ and the natural remanent magnetization (NRM) were measured using a Kappa Bridge (KLY-2) and DSM-2, SSM-2A Spinner Magnetometers (Schonstedt Company, U.S.A) at the room temperature. The Köenigsberger ratio (Q) was calculated as $N R M / J_{i}$, where $\mathrm{J}_{\mathrm{i}}$ is the induced magnetization $(=\kappa \times \mathrm{H}, \mathrm{H}$ being the local geomagnetic field intensity, $\mathrm{H}=0.05089 \mathrm{mT}$ ).

[8] Magnetic hysteresis loops were measured on powdered samples using an automated Princeton Measurements Vibrating Sample Magnetometer (VSM Model 3900). The maximum field was $2.0 \mathrm{~T}$. Magnetic hysteresis parameters (saturation magnetization, $\mathrm{M}_{\mathrm{s}}$, saturation isothermal remanent magnetization, $\mathrm{M}_{\mathrm{rs}}$, intrinsic coercivity, $\mathrm{B}_{\mathrm{c}}$ ) were calculated by subtracting the paramagnetic contribution $\left(\chi_{\text {para }}\right.$, the high-field slope). The remanent coercivity $\left(B_{c r}\right)$ was determined by the back-field DC demagnetization of $\mathrm{M}_{\mathrm{rs}}$. Isothermal Remanent Magnetization (IRM) curves were measured in applied field of $1 \mathrm{~T}$. The ferrimagnetic susceptibility $\left(\chi_{\text {ferr }}\right)$ is calculated by substracting $\chi-\chi_{\text {para }}(\chi$ is the bulk magnetic susceptibility). We use the ratio $\chi_{\mathrm{ferr}} / \chi_{\text {para }}$ to quantify the relative contributions of the ferrimagnetic and paramagnetic fractions to $\chi$. To further characterize components of the magnetic carrier in our samples, various thermomagnetic curves were measured, which included the temperature-dependence of mass susceptibility $\chi$, high-low temperature curves of saturation isothermal remanent magnetization (SIRM), and the stepwise thermal demagnetization of $\mathrm{J}_{\mathrm{N}}(\mathrm{NRM})$. Density $(\rho)$ was measured using a LP-1002 gravity densimeter, with a resolution of $0.01 \mathrm{~g} / \mathrm{cm}^{3}$ and a corresponding precision of $0.03 \%$. Magnetic hysteresis and thermomagnetic experiments and alternated field (AF) demagnetization of SIRM were performed using standard magnetic equipments and measuring conditions in the Paleomagnetism and Geochronology Laboratory, Institute of Geology and Geophysics, Chinese Academy of Sciences (CAS) and the State Key Laboratory of Geological Processes and Mineral Resources in China (Wuhan).

\subsection{Mineralogical Analyses}

[9] Based on the magnetic measurements, special samples $(83,86$ and 89$)$ were chosen for optical, electronic scanning microscopy (SEM), electron microprobe analysis (EMP), X-ray diffraction (XRD) and Raman spectroscopy. Polished thin sections of the specimens were examined under both transmitted and reflected lights. EMP analyses were performed using a JEOL JCXA-733 electron microprobe, using $15 \mathrm{kv}$ accelerating voltage, sample current of $10 \mathrm{nA}$ and a beam diameter of $1 \mu \mathrm{m}$. Mineral texture analysis was 

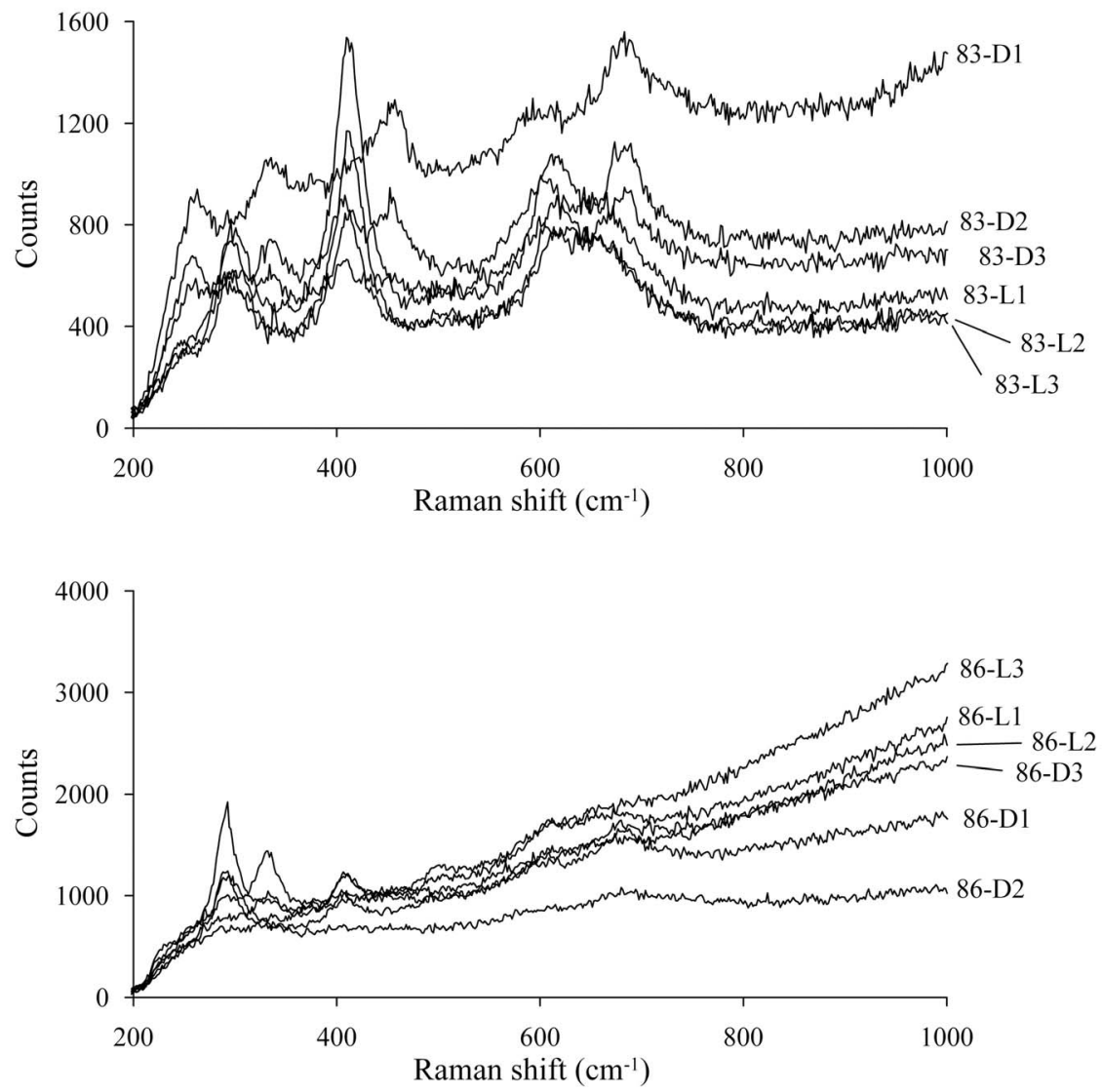

Figure 2. Micro-Raman spectra of the exsolved lamellar microstructures for samples 83 and 86 . L-light area; D-dark area.

conducted using a JEOL JSM-35CF SEM equipped with an energy dispersive spectrometer (EDS) and backscatter detector. The EDS spectra were collected at a beam current of $8.5 \mathrm{nA}$ at $20 \mathrm{kv}$ using a working distance of $11.5 \mathrm{~mm}$. $\mathrm{X}$-ray diffraction (XRD) spectrum (from sample 83) was obtained with a KC-106 diffractometer using a voltage of $15 \mathrm{kV}$, a current of $40 \mathrm{~mA}$ and a 2 theta range of $5-65^{\circ}$. Micro-Raman spectrum analyses for samples 83 and 86 were performed by using Renishaw Company (U.K).

\section{Results}

\subsection{Petrologic and Mineralogical Analyses}

\subsubsection{The Mineral Assemblage}

[10] Photomicrographs of samples studied are shown in Figure 1. The mineral assemblage is observed in the high $\mathrm{Fe}-\mathrm{Ti}$ eclogites is $\mathrm{Grt}+\mathrm{Omp}+\mathrm{Qtz}+\mathrm{Phn}+\mathrm{Ap} \pm(\mathrm{Rt}$, (ilm + Hem), $\mathrm{FeS}_{2}$ ) [Zhang et al., 2006; Y. Liu et al., 2007; Zeng et al., 2009]. Results indicate that hematite and ilmenite abundances are up to $25 \%$, pyrite is present in abundances of around 1\% (Table 1). Magnetite is not evident in any thin section. In addition, XRD analyses for whole rock of sample 83 showed only hematite and ilmenite, with hematite $>$ ilmenite and there were no magnetite peaks. Raman spectroscopy for exsolved lamellar microstructures [Shebanova and Lazor, 2003; Wang et al., 2004] shows that well-established hematite bands are clearly visible at $411-413,615-632,295-299 \mathrm{~cm}^{-1}$ for sample 83 and 291-293, 407-411, $612 \mathrm{~cm}^{-1}$ for sample 86 (Figure 2), which corresponds to standard values of hematite $\left(420,625,680,250\right.$ and $310\left(\mathrm{~cm}^{-1}\right)$. The ilmenite bands (D) were located at $683-687,598-605,457-458,409,332-336$ and $258-262\left(\mathrm{~cm}^{-1}\right)$ for sample 83 and $677-686,326-$ $334\left(\mathrm{~cm}^{-1}\right)$ for sample 86 , respectively (Figure 2). The additional bands in Raman spectrum for two samples might be the results of other minor minerals surrounding the host mineral. However, Raman spectra of relic magnetic inclusion in sample 83 can be clearly observed at $672-676,548-558$, 296-306, and 409-411 $\left(\mathrm{cm}^{-1}\right)$ (Figure 3 and Table 2) which is close to values of magnetite $\left(668,538,306\right.$ and $193\left(\mathrm{~cm}^{-1}\right)$ [Shebanova and Lazor, 2003].

\subsubsection{Lamellar Microstructures and Chemical} Analyses

[11] SEM analysis indicates that the samples contain ilmenite host grains with several generations of hematite exsolution lamellae lying parallel to (0001) (Figure 4). In the first-generation lamellae, the largest width is less than $10 \mu \mathrm{m}$ in sample 83 (Figure 4a). In samples 86 and 89 (Figures $4 b$ and $4 \mathrm{c}$ ), however, the largest width is approximately $50 \mu \mathrm{m}$. In sample 86, the first-generation lamellae are not parallel to (0001) (Figure 4b), whereas the second-generation lamellae are (Figure 4d). Sample 83 contains ilmeno-hematite, which consists of a hematite host with several generations of ilmenite exsolution (Figure 4a). In sample 86, first- 


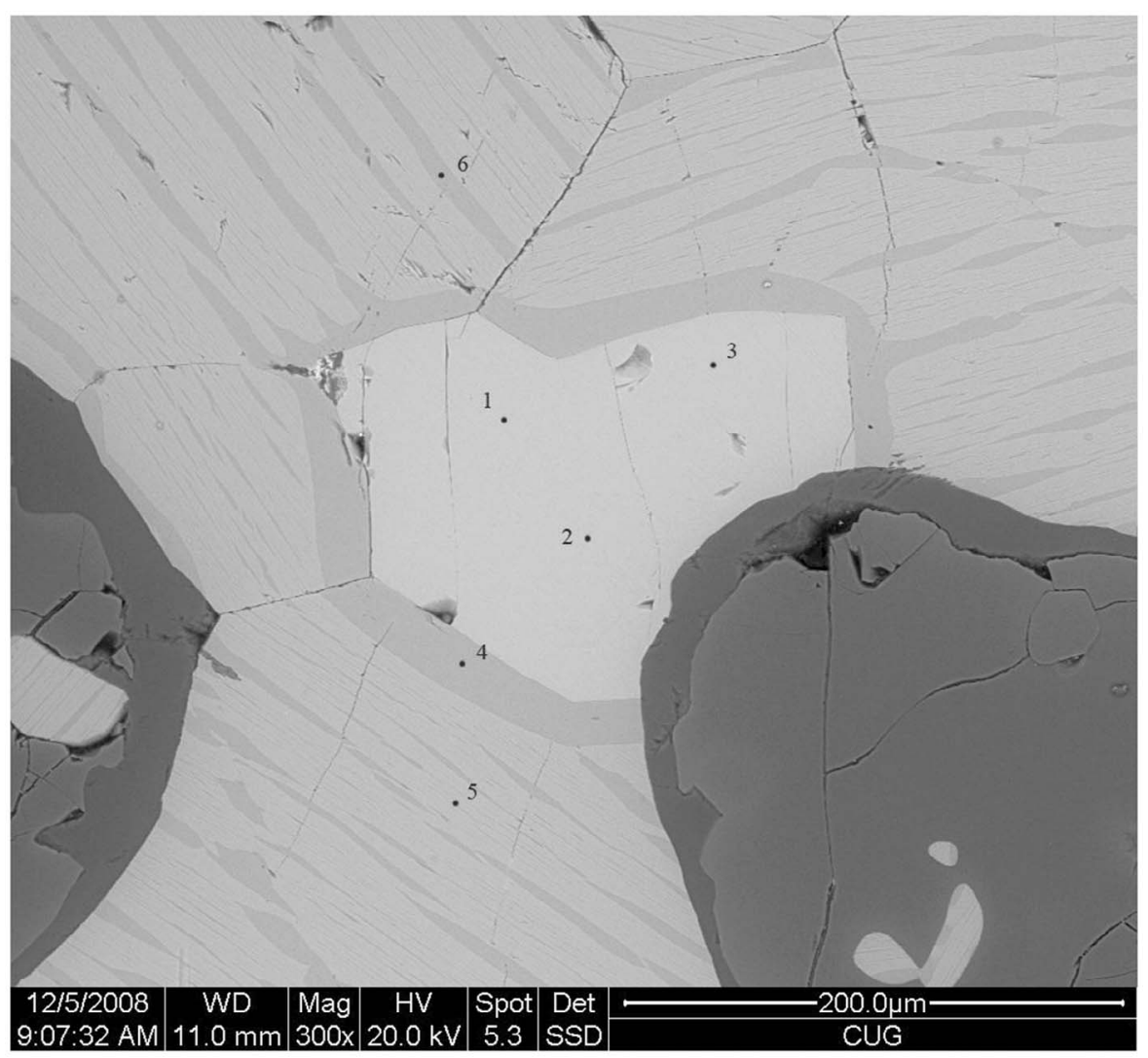

Figure 3. SEM image for sample 83. Exsolution lamellar textures and relic magnetite cluster surrounded by dark margin indicating ilmenite. It indicates magnetite cluster within exsolved lamellar of ilmeno-hematite.

generation lamella generally contains very fine secondgeneration lamellae (Figures $4 \mathrm{~b}$ and $4 \mathrm{~d}$ ). This might be caused by the cutting of the sample into thin section that would affect how the lamellae looks. These are most likely parallel to 0001. This is the shared interface between ilmenite and hematite and their element concentration is shown in Table 3.

[12] EMP analysis for lamellar microstructures shows that the dark areas observed in exsolved microstructures are ilmenite with an average $\mathrm{FeO}_{\mathrm{T}}$ of $52.34 \%$, and $\mathrm{TiO}_{2}$ of $45.97 \%$, whereas light areas correspond to hematite with an average $\mathrm{FeO}_{\mathrm{T}}$ of 77.88 , and $\mathrm{TiO}_{2}$ of $14.90 \%$ (Table 4). Concentrations of $\mathrm{Cr}_{2} \mathrm{O}_{3}, \mathrm{MgO}$, and $\mathrm{Al}_{2} \mathrm{O}_{3}$ in ilmenite from sample 86 are higher than those of samples 83 and 89 (Table 4). Ilmenite has higher level of $\mathrm{MgO}$ than hematite exsolution (Tables 3 and 4). Magnetite grains are rare in our samples, magnetite inclusion does occur in sample 83 revealed by SEM as very fine exsolution from omphacite (Figure 3 ).

\subsection{Densities and Magnetic Properties}

\subsubsection{Density, Susceptibility and Natural Remanent Magnetization}

[13] Densities of samples range between 3750 and $3870 \mathrm{~kg} / \mathrm{m}^{3}$, susceptibility varies between 4.83 and $14.38 \times$ $10^{-3} \mathrm{SI}$, and the range of NRM values are between 1.238 and $38.971 \mathrm{~A} / \mathrm{m}$ (Table 1). The intensity of the current geomagnetic field in the Donghai County is $0.05089 \mathrm{mT}$ and the calculated induced magnetization $\left(\mathrm{J}_{\mathrm{i}}\right)$ ranges from 0.197 to $0.600 \mathrm{~A} / \mathrm{m}$. Thus the corresponding Köenigsiberger ratio
(Q, defined as the ratio of NRM to $\mathrm{J}_{\mathrm{i}}$ ) varies between 2.68 and 64.97 (Table 1). These values indicate that magnetism observed in our samples is dominated by NRM instead of the induced magnetization (Table 1).

Table 2. Raman Spectrum Data of Specify Minerals for Exsolution Lamellae in Samples 83 and $86^{\mathrm{a}}$

\begin{tabular}{|c|c|c|c|c|c|c|c|}
\hline \multirow{2}{*}{$\frac{\text { Sample }}{\text { 83-D1 }}$} & \multicolumn{6}{|c|}{ Raman Shift $\left(\mathrm{rcm}^{-1}\right)$} & \multirow{2}{*}{$\begin{array}{c}\text { Inferred Major } \\
\text { Fe-oxide Mineral }\end{array}$} \\
\hline & 683 & 457 & 332 & 262 & & & \\
\hline 83-D2 & 687 & 605 & 458 & 409 & 336 & 258 & Ilmenite \\
\hline 83-D3 & 685 & 598 & 409 & 333 & 258 & & Ilmenite \\
\hline 86-D1 & 682 & 331 & & & & & Ilmenite \\
\hline $86-\mathrm{D} 2$ & 686 & 326 & 284 & & & & Ilmenite \\
\hline 86-D3 & 677 & 334 & & & & & Ilmenite \\
\hline 83-L1 & 411 & 615 & 299 & & & & Hematite \\
\hline $83-\mathrm{L} 2$ & 413 & 616 & 295 & & & & Hematite \\
\hline 83-L3 & 411 & 632 & 296 & & & & Hematite \\
\hline 86-L1 & 291 & 411 & 612 & & & & Hematite \\
\hline $86-\mathrm{L} 2$ & 291 & 407 & & & & & Hematite \\
\hline 86-L3 & 293 & 408 & & & & & Hematite \\
\hline 83-M-D1 & 681 & 331 & 298 & 588 & & & Ilmenite \\
\hline 83-M-D2 & 330 & 685 & 292 & & & & Ilmenite \\
\hline 83-M-C1 & 674 & 552 & 298 & 411 & & & Magnetite \\
\hline 83-M-C2 & 674 & 550 & 296 & 409 & & & Magnetite \\
\hline 83-M-C3 & 676 & 558 & & & & & Magnetite \\
\hline 83-M-C4 & 672 & 548 & 306 & & & & Magnetite \\
\hline
\end{tabular}

${ }^{\mathrm{a}}$ Note: $83-\mathrm{D} 1 \sim 86-\mathrm{D} 3$ and $83-\mathrm{L} 1 \sim 86-\mathrm{L} 3$ denote dark and light areas in exsolution lamellar textures. 83-M-D1 and 83-M-D2 denote dark areas around magnetite cluster in sample 83. 83-M-C1 83-M-C4 denote central areas in magnetite cluster of sample 83. 


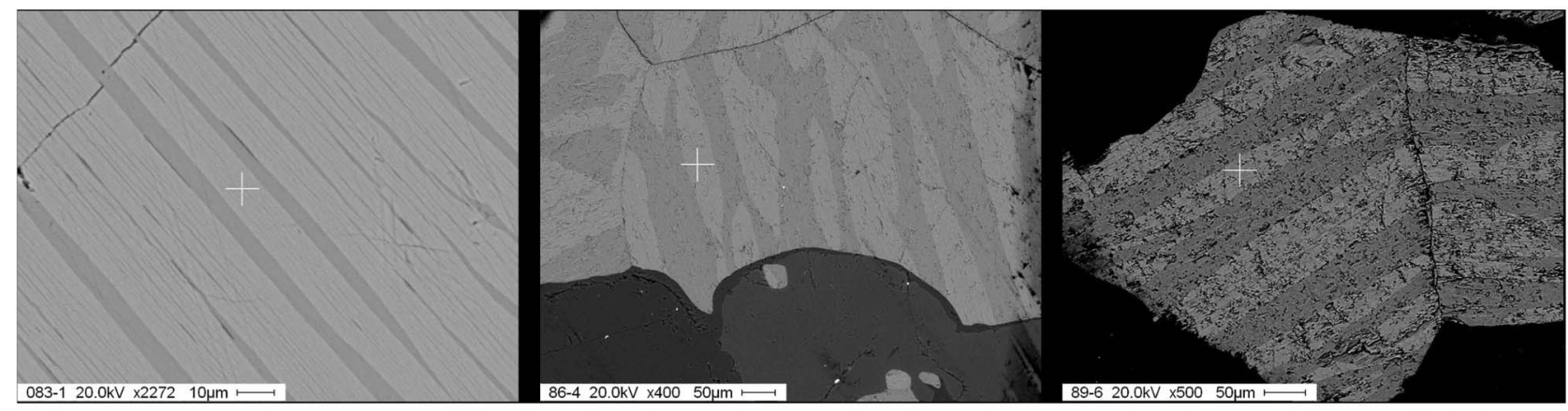

a

b

c

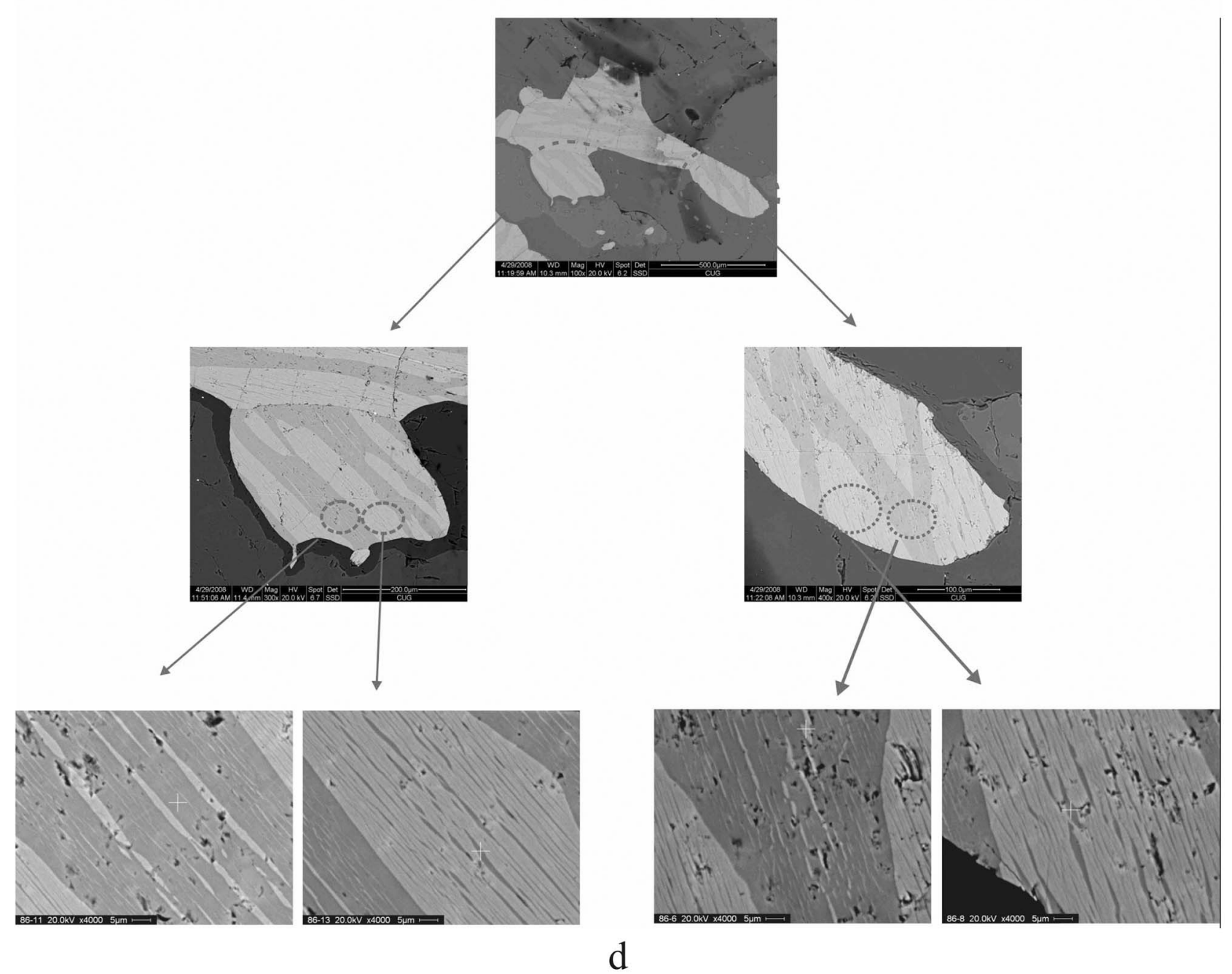

Figure 4. SEM images of samples (a) 83, (b) 86, (c) 89 and (d) magnified lamellar structures in sample 86. Several generations of lamellar microstructures are visible.

\subsubsection{Thermomagnetic Analyses}

[14] We used thermomagnetic analysis to identify magnetic phases and evaluate the effect of lamellar microstructures on NRM through unblocking temperatures $\left(\mathrm{T}_{\mathrm{B}}\right)$ (Figures 5, 6, and 7). Curie temperature $T_{\mathrm{c}}$ of $585^{\circ} \mathrm{C}$ observed in samples studied indicates that the principal magnetic carrier is magnetite (Figure 5). Sample 83 exhibits a relatively reversible pattern, which indicates no chemical transformation during the heating and cooling processes. In sample 86, the cooling curve is much higher than the heating curve, but the Curie temperature indicates that magnetite is the magnetic phase. The irreversibility simply indicates that additional magnetite is created during heating, by the alteration of some other 


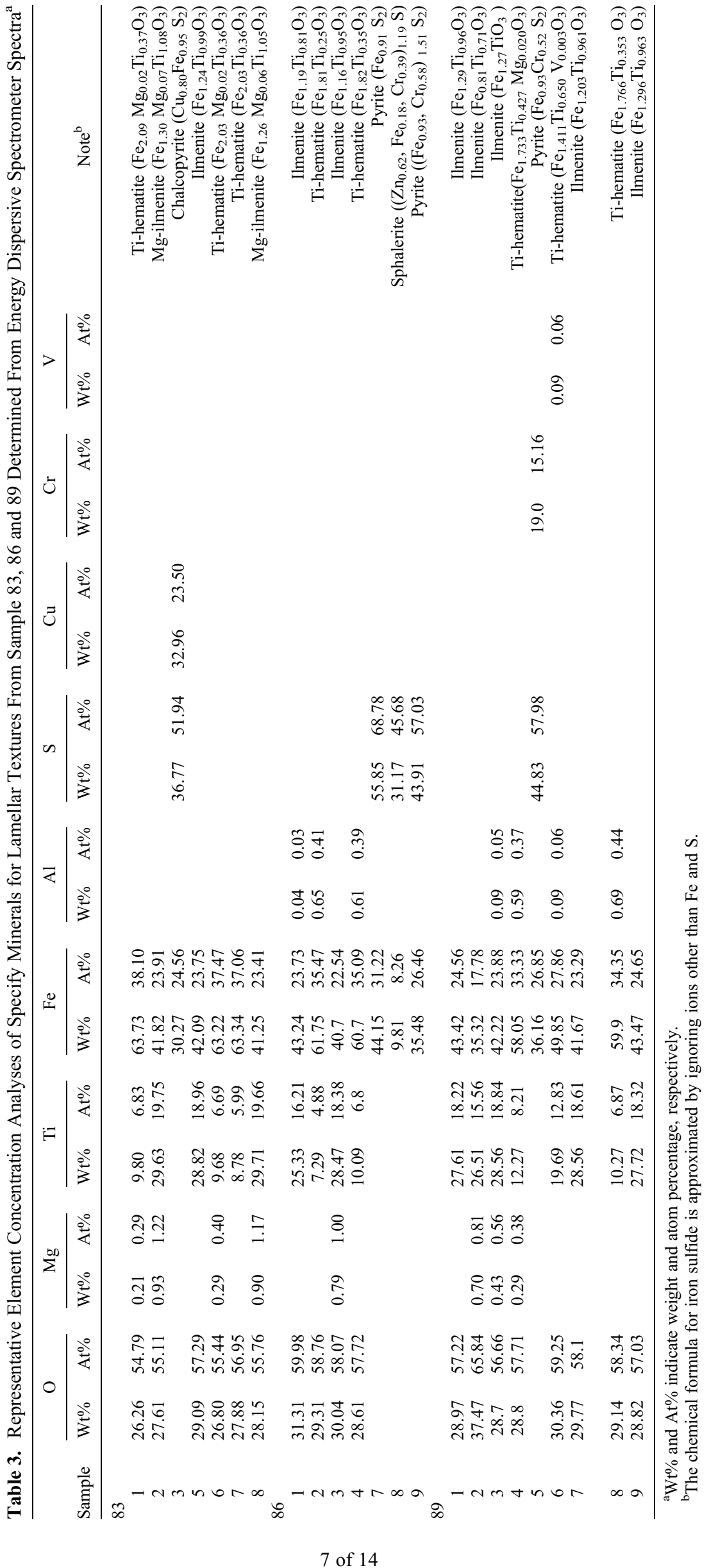




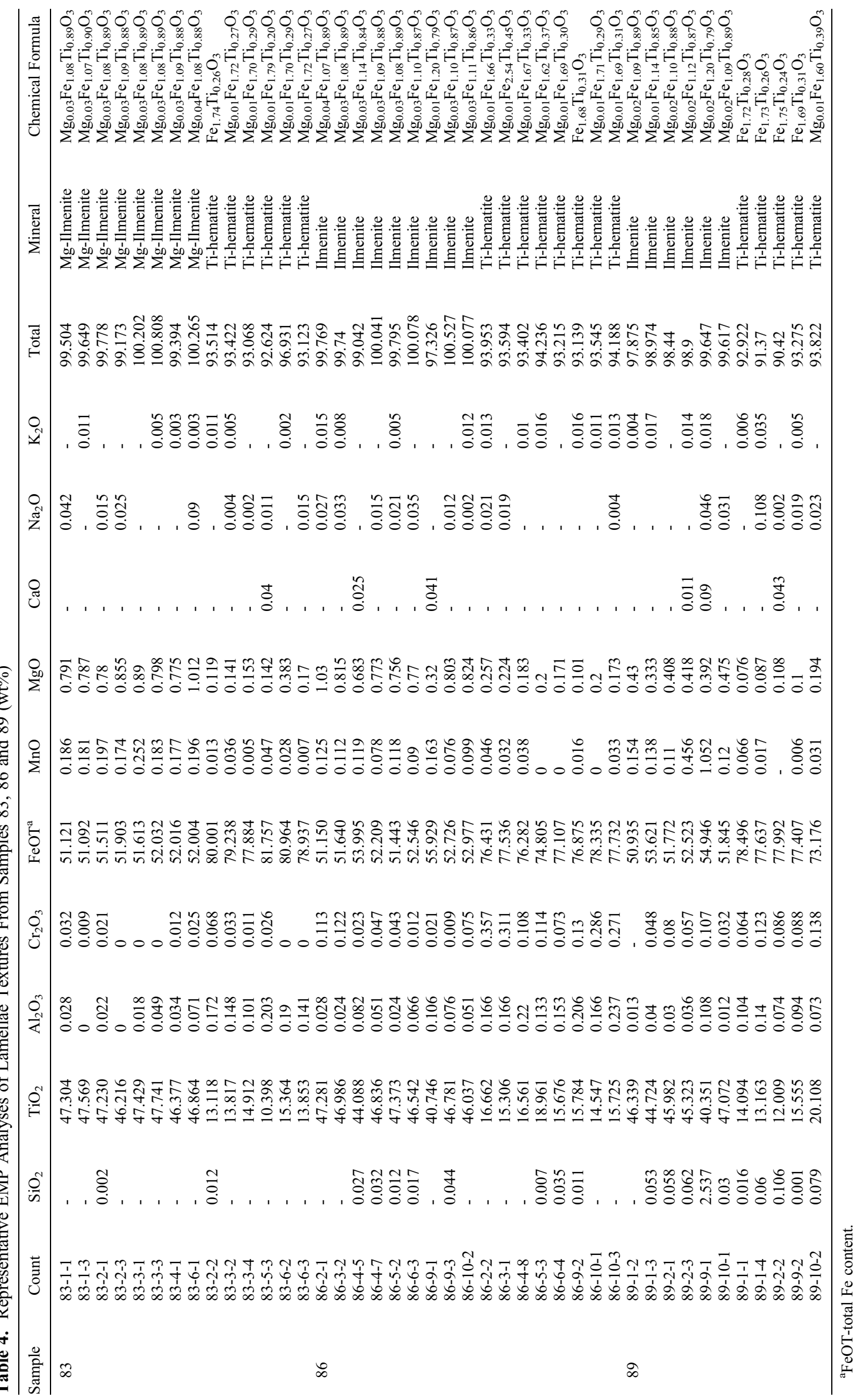



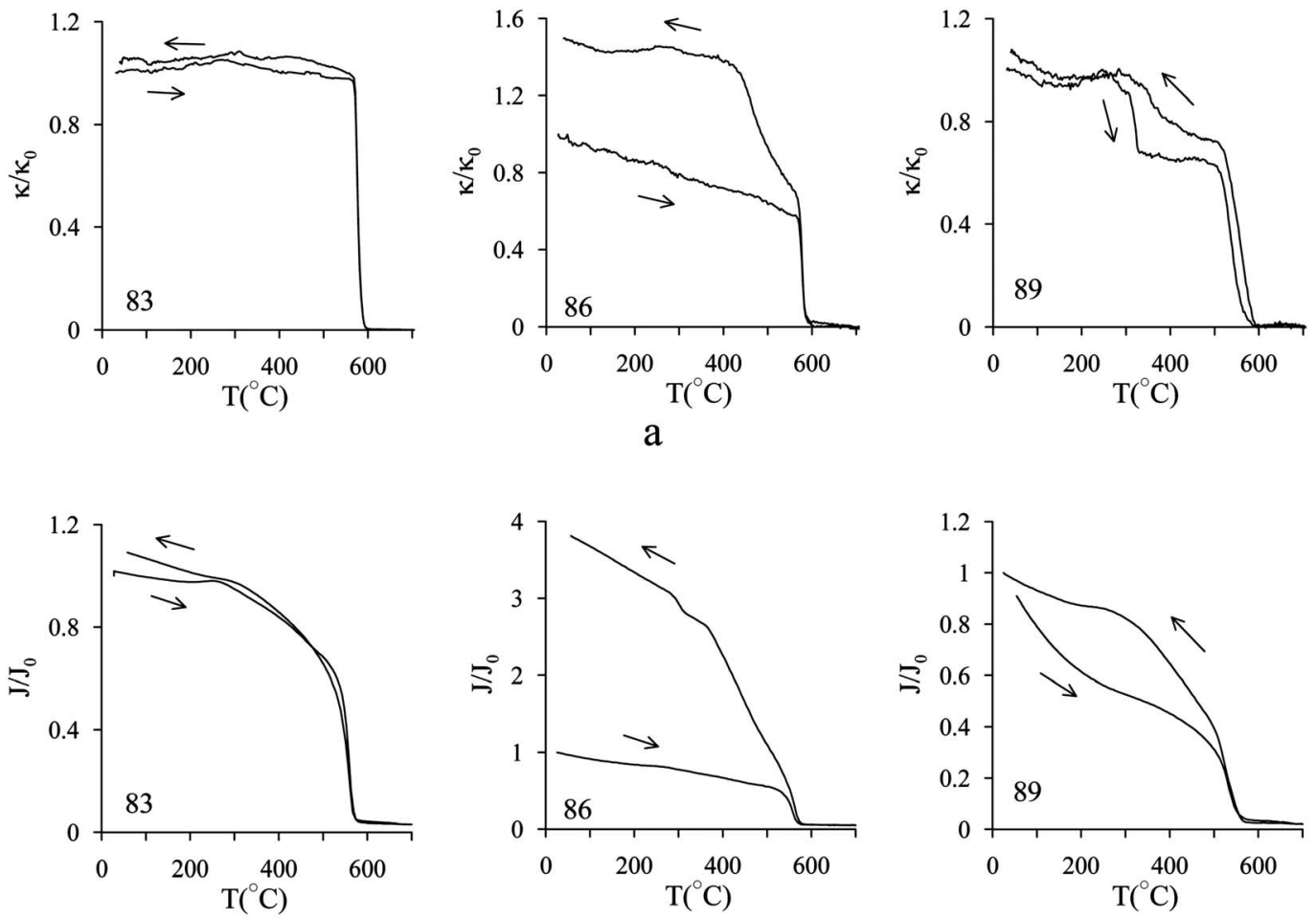

b

Figure 5. Temperature dependence of (a) $\chi$, (b) SIRM. Here $\chi$ and SIRM are mass susceptibility and saturation isothermal remanent magnetization. Arrows represent the heating/cooling process.

iron-bearing phase (Figure 5a). Two stable magnetic components are shown in sample 89 which correspond to pyrrhotite $\left(T_{\mathrm{c}}=325^{\circ} \mathrm{C}\right)$ and magnetite $\left(T_{\mathrm{c}}=585^{\circ} \mathrm{C}\right)$ (Figure 5a). J - T curves of three samples are very similar to those of $\kappa-\mathrm{T}$ (Figure $5 \mathrm{~b}$ ). The unblocking temperature $\left(T_{B}\right)$ during thermal demagnetization of NRM is of ca. $600^{\circ} \mathrm{C}$ (Figure 6). There is a tiny fraction of remanence that survives heating to $600^{\circ} \mathrm{C}$ in all three samples, and it is slightly larger in sample 89 (Figure 6). Low-temperature measurements display several interesting features (Figure 7). With continued heating, remanence is lost in samples 83 and 89 at $120 \mathrm{~K}$ as the Verwey transition for magnetite is crossed [Verwey et al., 1947]. More than 50\% of the remanence is lost below $25 \mathrm{~K}$ in samples 83 and
86; for sample 89 it is $>20 \%$. It possibly indicates that concentration of superparamagnetic (SP) grain in samples 83 and 86 is higher than that of sample 89. The Verwey transition of magnetite is invisible in sample 86 (Figure 7).

4.2.3. Measurements of Hysteresis, IRM Curves and AF Demagnetization of SIRM

[15] Hysteresis measurements indicate that in addition to their characteristic ferrimagnetic behavior, the samples studied contain a prominent paramagnetic component (Figure 8), ferrimagnetic and paramagnetic susceptibility ratios $\left(\chi_{\text {ferr }} / \chi_{\text {para }}\right)$ vary between 0.78 and 5.38 (Table 1$)$. $\mathrm{M}_{\mathrm{s}}$ and $\mathrm{M}_{\mathrm{rs}}$ vary between 110.85 and $291.84 \times 10^{-3}$ $\mathrm{Am}^{2} \mathrm{~kg}^{-1}$, and 13.72 and $60.01 \times 10^{-3} \mathrm{Am}^{2} \mathrm{~kg}^{-1}$, respectively. $\mathrm{M}_{\mathrm{rs}} / \mathrm{M}_{\mathrm{s}}$ ratios vary from 0.11 to 0.22 and
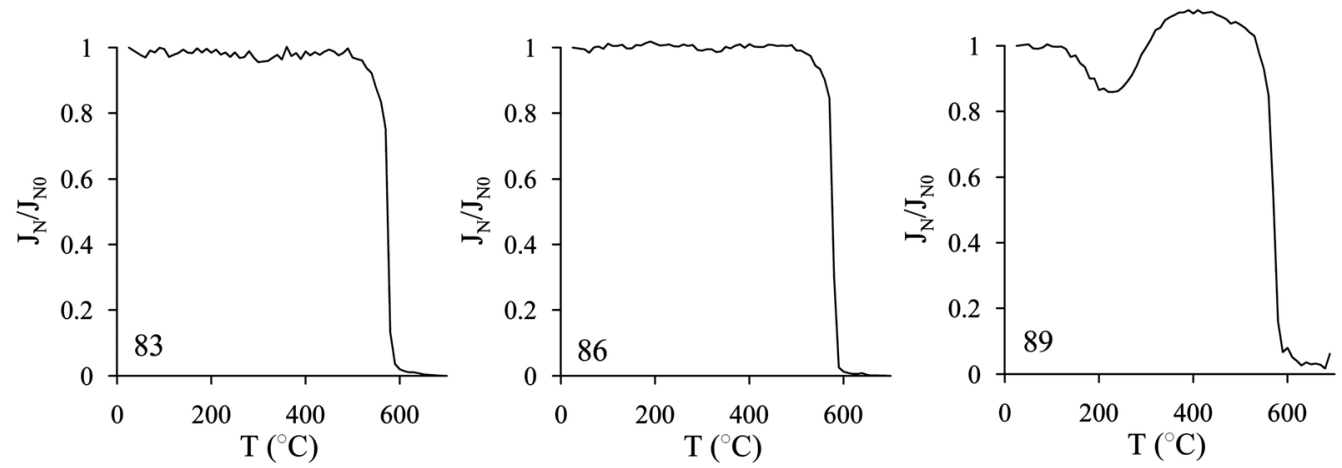

Figure 6. Stepwise thermal demagnetization curves of natural remanent magnetization (NRM). 


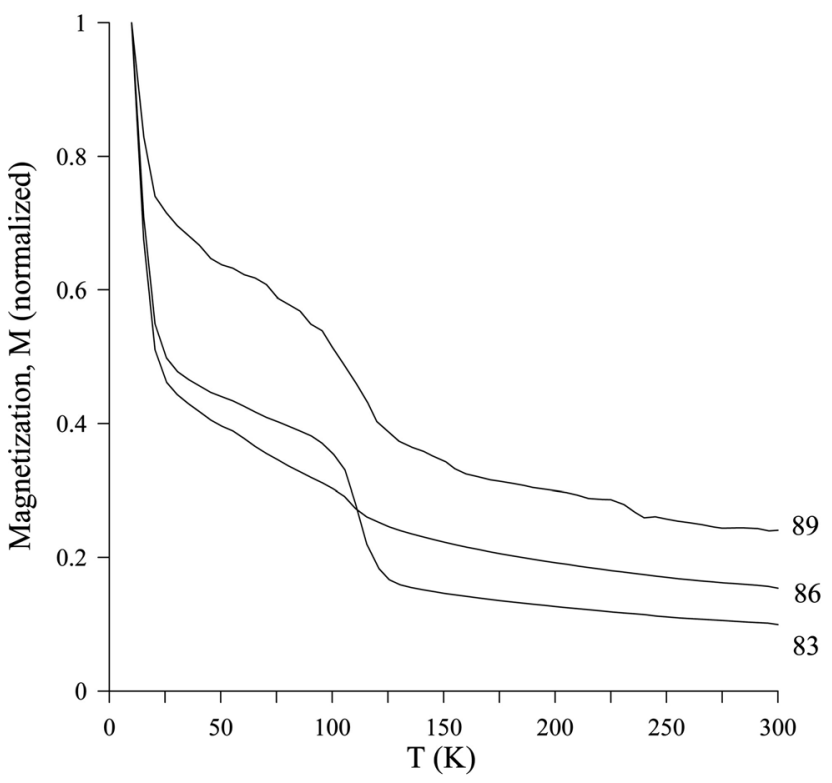

Figure 7. Low-temperature thermal demagnetization of SIRM, normalized to remanences at $20 \mathrm{~K}$. Numbers indicates the sample name.

$\mathrm{H}_{\mathrm{cr}} / \mathrm{H}_{\mathrm{c}}$ ratios are within the range 1.56-17.62 (Table 1). We observe significant magnetic differences in IRM and AF demagnetization curves of SIRM for samples studied (Figures 9 and 10).

\section{Discussions and Implications}

\subsection{Origin of Magnetism of Fe-Ti-Rich Eclogites}

[16] From the thermomagnetic and mineralogical data, we interpret that magnetic phases in samples studied belong to dominantly (titan)magnetite series (magnetite and titanomagnetite), ilmenite-hematite solid solution and Fe-sulfides (pyrrhotite), but concentration of magnetic minerals is generally low. From $\mathrm{M}_{\mathrm{rs}} / \chi, \mathrm{H}_{\mathrm{cr}} / \mathrm{H}_{\mathrm{c}}-\mathrm{M}_{\mathrm{rs}} / \mathrm{M}_{\mathrm{s}}$ ratios, we can observe that magnetic components in samples 83 and 86 are mainly (titano)magnetite and SD-PSD behavior (Table 1) [Dunlop, 2002; Peters and Dekkers, 2003]. The level of magnetite is low in samples studied corresponding to lower

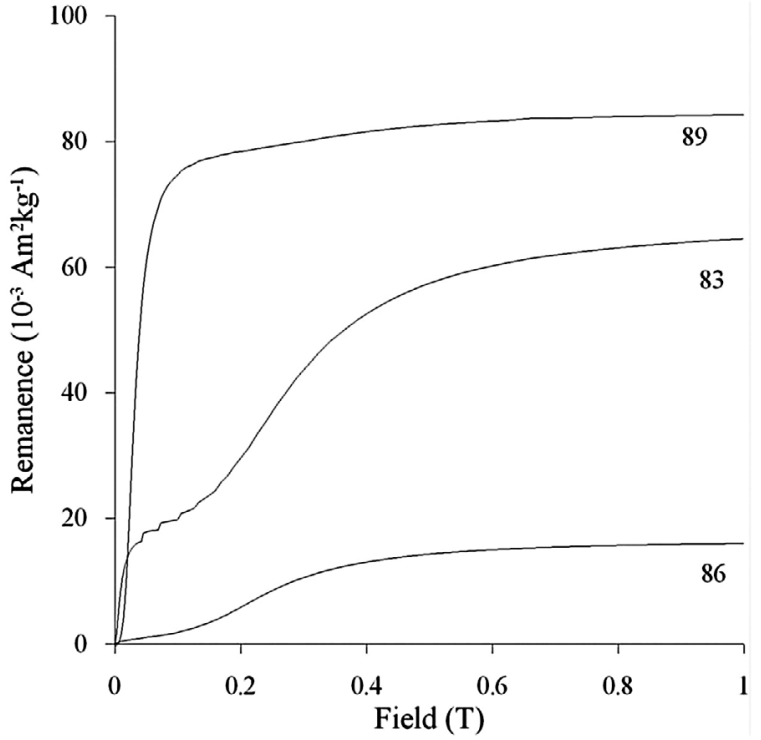

Figure 9. Plot showing isothermal remanent magnetization (IRM) curves for samples studied (maximum field is $1 \mathrm{~T}$ ).

ferromagnetic susceptibilities $\chi_{\text {ferr }}$ (Table 1). From the above observation, it is possible that a part of their NRM and paramagnetic signature comes from the abundant ilmenohematite (Tables 1 and 2). Robinson et al. [2002, 2004] have suggested that hemo-ilmenite with a lamellar microstructure can have a saturation magnetization of up to $55 \mathrm{kA} / \mathrm{m}$. In samples studied, we observe unblocking temperatures of ca. $600^{\circ} \mathrm{C}$ which reflects the effects of the Ti element on the $\mathrm{T}_{\mathrm{B}}$ (Figure 6) [Feinberg et al., 2006]. We observe a highly exsolved ilmeno-hematite and minor (titano)magnetite in samples studied (Figures 1, 3, 4 and Tables 1, 2, 3) which makes quantifying the contribution of both ilmeno-hematite with lamellar structure and (titano)-magnetite to the NRM be difficult.

[17] The values of $\chi, M_{s}$, and $M_{r s}$ in sample 86 are always lower than those in samples 83 and 89 (Table 1). Sample 86 has the lowest $\chi_{\text {ferr }} / \chi_{\text {para }}$ ratio $(0.78)$ and this ratio in sample 89 is slightly higher than that in sample 83 (Table 1). In addition, we observe a high magnetic stability in samples 86 and 83 (Figure 10), however, the remanent coercivity in
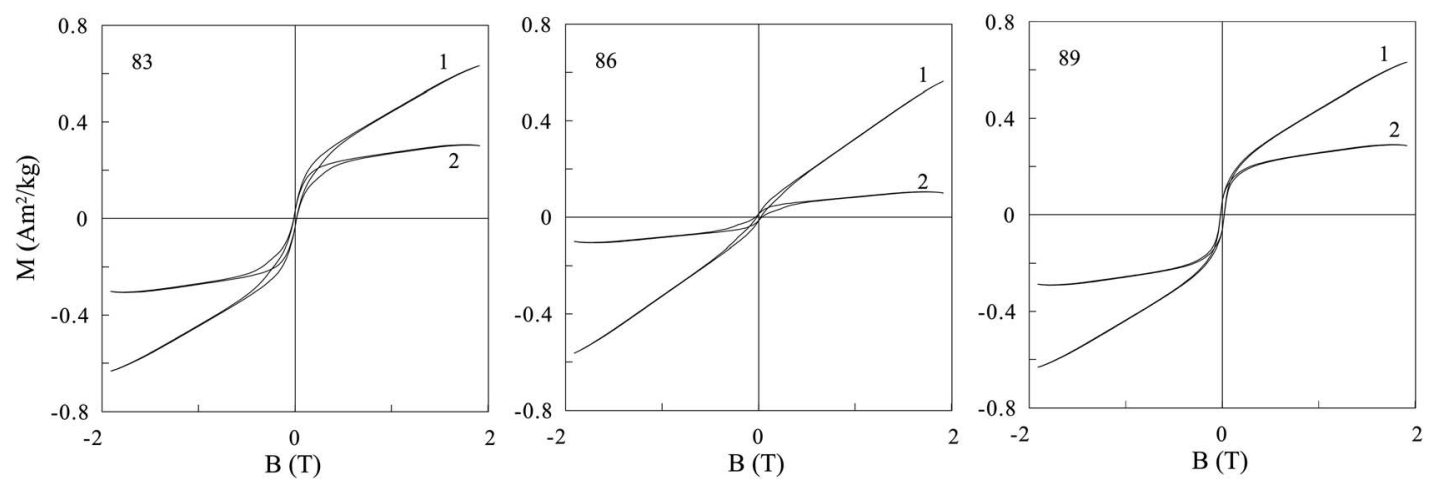

Figure 8. Magnetic hysteresis loops of samples 83, 86 and 89 before (1) and after (2) correction for the paramagnetic contributions. 


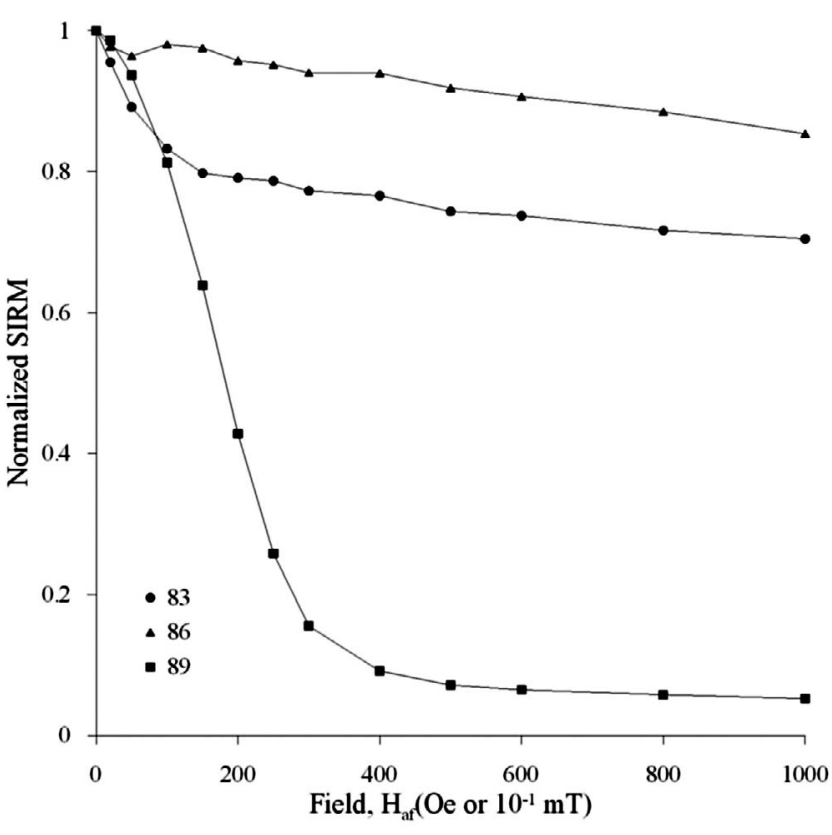

Figure 10. Alternating field (AF) demagnetization curves of SIRM of samples studied. Sample 89 contains magnetic mineral with low coercivity.

sample 89 (magnetite) is low (Figure 10 and Table 1). This indicates that the relative contributions of ferrimagnetic susceptibility to bulk susceptibility in our samples are the highest in sample 89, second in sample 83, and lowest in sample 86 (Table 1). Figure 6 shows that the thermal unblocking temperature $\left(T_{B}=\right.$ ca. $\left.600^{\circ} \mathrm{C}\right)$ of sample 83 is very similar to that of sample 86 which seem to be caused by titan-ilmeno-hematite composition [Kletetschka and Stout, 1998] and this temperature is up to $670^{\circ} \mathrm{C}$ in sample 89 which are close to those of hemo-ilmenite ores and granulite-facies rocks observed in other sites (Table 5) [McEnroe et al., 2001a; Kletetschka et al., 2002; Kasama et al., 2004]. These characteristics are remarkably different from those of the UHP eclogites that lack highly exsolved ilmeno - hematite $[Q$. Liu et al., 2007, 2009].

[18] We observe a large difference in exsolution textures and mineral concentration of the ilmeno- hematite (Figures 1 and 4), which could be the reason why sample 83 has high susceptibility and high NRM, whereas sample 86 has relatively low susceptibility but a moderate NRM and sample 89 has high susceptibility and very low NRM (Table 1). In sample 83, lamellas are usually narrower than $1 \mu \mathrm{m}$ and lie parallel to the (0001) planes of the host (Figure 4a). In contrast, in samples 86 and 89 the lamellas are generally wider than $10 \mu \mathrm{m}$ and are not parallel to (0001) planes of the host (Figures $4 \mathrm{~b}$ and $4 \mathrm{c}$ ). Sample 86, with a moderate NRM, exhibits second-generation narrow lamellae which is parallel to (0001) (Figure 4d). This is consistent with the observation reported in Robinson et al. [2002] which proposed that the intensity of lamellar magnetism increases when: (1) the proportion of exsolved lamellar material is large, (2) lamellae are of minimal thickness and maximum abundance, maximizing the surface area of contact layers, and (3) host (0001) planes are parallel to the magnetizing field, promoting in - phase magnetization. This suggests that the high concentration of hemo-ilmenite in sample 83 and its lamellar microstructure might be the source of its high intensity NRM.

[19] Except for the minor change in magnetic intensity observed at ca. $220^{\circ} \mathrm{C}$, the experiments of $\kappa-\mathrm{T}$ and $\mathrm{J}-\mathrm{T}$ show that magnetism in sample 89 is carried by Fe-sulfides and magnetite (Figures 5, 6 and Table 3). Figure 5 shows that the predominant ferro-magnetic component has a $T_{c}$ of $581^{\circ} \mathrm{C}$ in sample 83 and $576^{\circ} \mathrm{C}$ in sample 86 which might be the composition of magnetite. Cooling curves, however, are always higher than the heating curves in the sample 86, which indicates that additional magnetite is created during heating, by alteration of some other iron-bearing phase. This is consistent with relatively low susceptibility and higher concentrations of minor elements $\left(\mathrm{Cr}_{2} \mathrm{O}_{3}, \mathrm{MgO}\right.$, and $\left.\mathrm{Al}_{2} \mathrm{O}_{3}\right)$ in the magnetite-series minerals $(0.60 \%$ in sample 86 ; $>0.40 \%$ in samples 83 and 89 ) (Figure 5 and Tables 1 and 4). These diverse magnetic experiments and measurements suggest that eclogites with and without exsolved phase of the ilmeno-hematite solid solution have different magnetic properties. However, it is difficult to identify the Curie point between magnetite and hemo-ilmenite or ilmeno-hematite solid solution, as a $\mathrm{T}_{\mathrm{c}}$ of the hemo-ilmenite and ilmenohematite, some of which may have some compositions with $\mathrm{T}_{\mathrm{c}}$ in the range of $580-600^{\circ} \mathrm{C}$.

[20] We compare magnetite micro-inclusions within clinopyroxene relic magnetite in sample 83 (Figure 3) to those observed in other clinopyroxenes [Frandsen et al., 2004; Feinberg et al., 2005] and magnetite nanoparticles [SantoyoSalazar et al., 2007], all of which have been regarded as sources of highly stable remanent magnetization [Renne et al., 2002; Feinberg et al., 2006]. It is observed that magnetite exsolved from the pyroxenes contributes to the high NRM signature of the oxide-rich eclogites, because individual magnetite crystal in the matrix is too coarsely grained to host the NRM. In the pyroxenes of these rocks, magnetite is exsolved because ferric iron is a commonly substitute for $\mathrm{Al}$ in high-P, $\mathrm{NaAlSi}_{2} \mathrm{O}_{6}$-rich pyroxenes were saturated in ferric iron during peak metamorphism.

[21] Natural Remanent Magnetization (NRM) of a rock depends mainly on its material constituent, geological origin and historical geomagnetic field. Pechersky [2007] observed high geomagnetic intensity events occurred in $230 \mathrm{Ma}, 8 \times$ $10^{22} \mathrm{Am}^{2} 190 \mathrm{Ma}$ ago and $10.5 \times 10^{22} \mathrm{Am}^{2} 120 \mathrm{Ma}$ ago (close to those suggested by Tarduno et al. [2001]). This could be the factor which generates the high NRM in high Fe-Ti eclogites [ $\mathrm{Liu}, 2011]$.

\subsection{Implications for Subduction Zone Magnetism and Exhumation Process of the UHP Eclogites}

[22] Most of the Sulu UHP eclogites are not ferromagnetic because, as discussed previously, Fe - Ti oxides were consumed at high pressures by solution of $\mathrm{Fe}^{3+}$ and $\mathrm{Ti}$ into garnet and clinopyroxene, and the pyroxene was not saturated with ferric iron magnetite which did not exsolve from the omphacite during retrogression. The magnetic properties of relatively scarce high $\mathrm{Fe}$ - Ti eclogites studied, with exsolved ilmeno-hematite and magnetite are comparable to those of hemo-ilmenite ores and high-grade metamorphic rocks containing exsolved hemo-ilmenite/ilmeno-hematite elsewhere (Table 5). For example, NRM values are between 


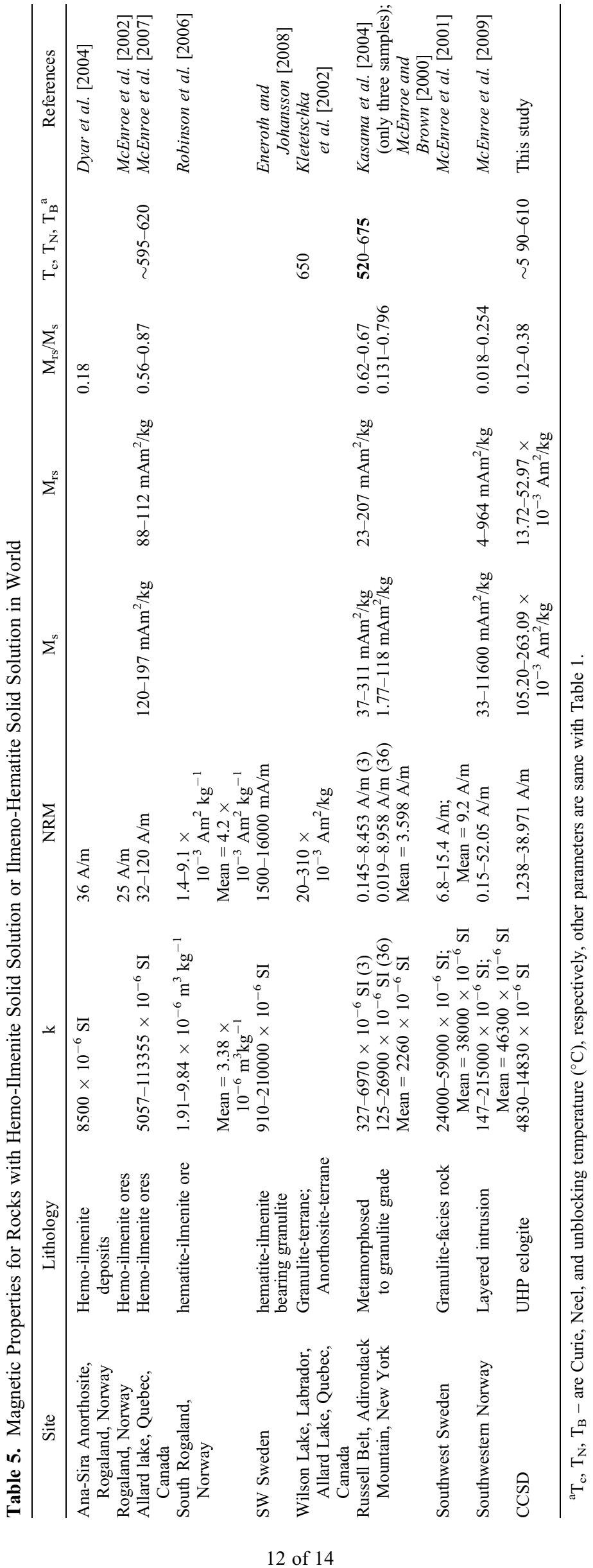


25 and $36 \mathrm{~A} / \mathrm{m}$ in hemo-ilmenite deposits in Ano-Sira Anorthosite, Rogaland, Norway [McEnroe et al., 2002; Dyar et al., 2004]. The layered intrusion from southwestern Norway vary between 0.15 and $52.05 \mathrm{~A} / \mathrm{m}$ [McEnroe et al., 2009] which are similar to $1.238-38.971 \mathrm{~A} / \mathrm{m}$ of samples studied in this paper (Table 5). The magnetic difference between our samples and those collected in other sites is mainly due to the variations of lithology levels in these samples (Table 5). In aeromagnetic and gravity anomaly maps of eastern China [Wu, 2001], we observe prominent high-magnetic anomalies associated with the fossil Sulu subduction zone. The intensity of the magnetic anomalies is always higher than $200 \mathrm{nT}$. Magnetic rocks in the Sulu area are dominantly retrograssed eclogites, serpentinized garnet peridotites, orthogneiss and high Fe-Ti eclogites with exsolution lamellar, respectively [Q. Liu et al., 2007, 2009, 2010]. Among them, high Fe-Ti eclogites have strong NRM and $Q$ values which are up to 64.97 for sample 83 (Table 1). We hence believe that these high Fe-Ti eclogites with lamellar structures might be the source of regional magnetic anomalies in the Sulu subduction zone, E. China $[\mathrm{Wu}, 2001]$.

[23] Generally speaking, except for NRM intensity depends much more strongly on properties of the recording material, to acquire a strong and stable NRM in rocks such as the high Fe-Ti eclogites, two conditions need to be satisfied: 1) a slow isobaric cooling process after peak metamorphism under elevated temperature (above $800^{\circ} \mathrm{C}$ ), and 2) an ambient high-intensity and constant field polarity during NRM blocking. These conditions can be easily met in the Sulu UHP metamorphic rocks in ca. 230-220 Ma ago. Ilmeno-hematite exsolution occurred during decompression under near isothermal conditions (ca. $850^{\circ} \mathrm{C}$ ) at an exhumation rates of $5.2-5.4 \mathrm{~km} / \mathrm{Ma}$, which were followed (ca. $190 \mathrm{Ma}$ ago) by a slow T decreasing (from $850^{\circ} \mathrm{C}$ to $400^{\circ} \mathrm{C}$ ) under near isobaric conditions (ca. $1 \mathrm{GPa})[Z . X u$ et al., 2009]. He et al. [2009] proposed that the temperature at the Moho boundary in the Sulu UHP metamorphic belt reaches above $750^{\circ} \mathrm{C}$ and depth of the Moho boundary is about $34 \mathrm{~km}$ [Yang, 2009]. If temperature acquired of NRM for high Fe-Ti eclogite with IHSS is about $450^{\circ} \mathrm{C}$ [Robinson et al., 2002], the corresponding depth should be $20.45 \mathrm{~km}$ which locates at the upper lower crust in the CCSD main hole site.

[24] Therefore, we suggest that NRM generated from high Fe-Ti eclogites with exsolution lamellae of samples studied is related to the tectonic setting in deep subduction and exhumation processes. This result agrees well with the mineral phase changes of exhumation and uplift processes [Z. Xu et al., 2009]. This indicates that magnetic properties of the high Fe-Ti eclogites presented in this paper will greatly contribute to the understanding of the exhumation process of the UHP metamorphic rock in the Sulu subduction zone, eastern China.

\section{Conclusions}

[25] There are various possible causes of the magnetic properties in high-Fe-Ti eclogites with lamellae-rich from the CCSD main hole, which controls the size of the exsolution lamellae in the ilmeno - hematite and magnetic minerals. Our studies show that, although the magnetic in many eclogites is weak, some eclogites are high magnetic susceptibility and NRM. This is because these eclogites are formed from gabbros that were originally oxide rich. During metamorphism to eclogite facies, Fe-Ti oxides, mostly a ferric-iron rich ilmenite, are likely to survive in these rocks, meaning that the coexisting pyroxenes will be saturated in ferric iron. The exsolution of magnetite from pyroxene and of hematite from hemo-ilmenite during cooling will produce phases that can carry a strong magnetic signature. Thus, in this paper, we observe that Fe-Ti-rich eclogites could generate a magnetic signature in the continental plate convergence zones. These Fe-Ti-rich eclogites might be one of the main sources of high-magnetic anomalies observed in the Sulu UHP metamorphic belt, eastern China.

[26] Acknowledgments. Q.S.L. and B.R.F. think David J. Dunlop and Subir K. Banerjee for very helpful discussions about magnetism of lower crustal rock and HISS, respectively. This paper was supported by Special Project of Deep Probe Technology and Experimental Research of Ministry by the Land and Resources of China (Sinoprobe-07-03) and National Natural Science Foundation of China (NSFC grant 41130315). We also thank Associate Editor Eric Ferre, B. Abalos, and S. A. McEnroe for their constructive comments, which significantly improved the quality of this paper.

\section{References}

Abalos, B., and A. Aranguren (1998), Anisotropy of magnetic susceptibility of eclogites: Mineralogical origin and correlation with the tectonic fabric (CaboOrtegal, Spain), Geodin. Acta, 11, 271-283, doi:10.1016/S09853111(99)80017-5

Banerjee, S. K. (1991), Magnetic properties of Fe-Ti oxides, Rev. Mineral., $25,107-128$.

Blakely, R. J., T. M. Brocher, and R. E. Wells (2005), Subductionzone magnetic anomalies and implications for hydrated forearc mantle, Geology, 33, 445-448, doi:10.1130/G21447.1.

Dunlop, D. J. (2002), Theory and application of the Day plot $\left(\mathrm{M}_{\mathrm{rs}} / \mathrm{M}_{\mathrm{s}}\right.$ versus $\mathrm{H}_{\mathrm{cr}} / \mathrm{H}_{\mathrm{c}}$ ): 2. Application to data for rocks, sediments, and soils, J. Geophys. Res., 107(B3), 2057, doi:10.1029/2001JB000487.

Dyar, M. D., S. A. McEnroe, E. Murad, L. L. Brown, and H. Schiellerup (2004), The relationship between exsolution and magnetic properties in hemo-ilmenite: Insights from Mössbauer spectroscopy with implications for planetary magnetic anomalies, Geophys. Res. Lett., 31, L04608, doi:10.1029/2003GL019076.

Eneroth, E., and L. Johansson (2008), Determination of magnetic properties of rocks by analysis of demagnetization curves: Hematite-ilmenite bearing rocks from SW Sweden, J. Geophys. Res., 113, B02101, doi:10.1029/2007JB004736.

Feinberg, J. M., G. R. Scott, P. R. Renne, and H. R. Wenk (2005), Exsolved magnetite inclusions in silicates: Features determining their remanence behavior, Geology, 33, 513-516, doi:10.1130/G21290.1.

Feinberg, J. M., R. J. Harrison, T. Kasama, R. E. Duni-Borkowski, G. R. Scott, and P. R. Renne (2006), Effects of internal mineral structures on the magnetic remanence of silicate-hosted titanomagnetite inclusions: An electron holography study, J. Geophys. Res., 111, B12S15, doi:10.1029/2006JB004498.

Florio, G., M. Fedi, A. Rapolla, D. M. Fountain, and P. N. Shive (1993), Anisotropic magnetic susceptibility in the continental lower crust and its implication for the shape of magnetic anomalies, Geophys. Res. Lett. 20, 2623-2626, doi:10.1029/93GL02237.

Frandsen, C., S. L. S. Stipp, S. A. McEnroe, M. B. Madsen, and J. M. Knudsen (2004), Magnetic domain structures and stray fields of individual elongated magnetite grains revealed by magnetic force microscopy, Phys. Earth Planet. Inter., 141, 121-129, doi:10.1016/j.pepi.2003.12.001.

Frost, B. R. (1991a), Stability of oxide minerals in metamorphic rocks, Rev. Mineral., 25, 469-488.

Frost, B. R. (1991b), Magnetic petrology: Factors that control the occurrence of magnetite in crustal rocks, Rev. Mineral., 25, 489-509.

Frost, B. R., and P. N. Shive (1986), Magnetic mineralogy of the lower continental crust, J. Geophys. Res., 91, 6513-6521, doi:10.1029/ JB091iB06p06513.

He, L., S. Hu, W. Yang, and J. Wang (2009), Radiogenic heat production in the lithosphere of Sulu ultrahigh-pressure metamorphic belt, Earth Planet. Sci. Lett., 277, 525-538, doi:10.1016/j.epsl.2008.11.022.

Kasama T., S. A. McEnroe, N. Ozaki, T. Kogure, and A. Putnis (2004), Effect of nanoscaleexsolution in hematite-ilmenite on the acquisition of 
stable natural remanent magnetization, Earth Planet. Sci. Lett., 224 , 461-475, doi:10.1016/j.epsl.2004.05.027.

Kletetschka, G., and J. H. Stout (1998), The origin of magnetic anomalies in lower crust rocks, Labrador, Geophys. Res. Lett., 25, 199-202, doi:10.1029/97GL03506.

Kletetschka, G., P. J. Wasilewski, and P. T. Taylor (2002), The role of hematite-ilmenite solid solution in the production magnetic anomalies in ground- and satellite-based data, Tectonophysics, 347, 167-177, doi:10.1016/S0040-1951(01)00243-8

Langel, R. A., and W. J. Hinze (1998), The Magnetic Field of the Earth's Lithosphere: The Satellite Perspective, Cambridge Univ. Press, New York, doi:10.1017/CBO9780511629549.

Liu, Q. (2011), Why are Q-ratios high in the Sulu UHP metamorphic rocks?, J. Earth Sci., 22, 115-116, doi:10.1007/s12583-011-0161-1.

Liu, Q., Q. S. Liu, Z. M. Zhang, H. J. Xu, L. S. Chan, T. Yang, and Z. M. Jin (2007), Magneticproperties of ultrahigh-pressure eclogites controlled by retrograde metamorphism: A case study from the ZK 703 drillhole in Donghai, eastern China, Phys. Earth Planet. Inter., 160, 181-191, doi:10.1016/j.pepi.2006.10.001

Liu, Q., Q. S. Liu, Y. S. Liu, S. Gao, T. Yang, Y. H. Luo, and Z. M. Jin (2008), Magnetic study of mafic granulite xenoliths from the Hannuoba basalt, North China, Geochem. Geophys. Geosyst., 9, Q06008, doi:10.1029/2008GC001952.

Liu, Q., Q. S. Liu, T. Yang, Q. L. Zeng, J. P. Zheng, Y. H. Luo, N. Qiu, H. J. Xu, and Z. M. Jin (2009), Magnetic study of the UHP eclogites from the Chinese Continental Scientific Drilling (CCSD) Project J. Geophys. Res., 114, B02106, doi:10.1029/2008JB005917.

Liu, Q. S., Q. L. Zeng, J. P. Zheng, T. Yang, N. Qiu, Z. F. Liu, Y. H. Luo, and Z. M. Jin (2010), Magnetic properties of serpentinized garnet peridotites from the CCSD main hole in the Sulu ultrahigh-pressure metamorphic belt, eastern China, J. Geophys. Res., 115, B06104, doi:10.1029/ 2009JB000814.

Liu, Y., H.-J. Yang, Y.-H. Shau, F. Meng, J. Zhang, J. Yang, Z. Xu, and S.-C. And Yu (2007), Compositions of high Fe-Ti eclogites from the Sulu UHP metamorphic terrane, China: HFSE decoupling and protolith characteristics, Chem. Geol., 239, 64-82, doi:10.1016/j.chemgeo.2006. 12.005 .

McBirney, A. R. (1998), The Skaergaard Layered Series. Part V. Included trace elements, J. Petrol., 39, 255-276, doi:10.1093/petroj/39.2.255.

McCammon, C. A., S. A. McEnroe, P. Robinson, K. Fabian, and B. P. Burton (2009), High efficiency of natural lamellar remanent magnetisation in single grains of ilmeno-hematite calculated using Mössbauer spectroscopy, Earth Planet. Sci. Lett., 288, 268-278, doi:10.1016/ j.eps1.2009.09.030.

McEnroe, S. A., and L. L. Brown (2000), A closer look at remanencedominated aeromagnetic anomalies: Rock magnetic properties and magnetic mineralogy of the Russell Belt microcline-sillimanite gneiss, northwest Adirondack Mountains, New York, J. Geophys. Res., 105, 16,437-16,456, doi:10.1029/2000JB900051.

McEnroe, S. A., P. Robison, and P. T. Panish (2001a), Aeromagnetic anomalies, magnetic petrology, and rock magnetism of hemo-ilmeniteand magnetite-rich cumulate rocks from the Sokndal region, south Rogaland, Norway, Am. Mineral., 86, 1447-1468.

McEnroe, S. A., Harrison, R. J., P. Robinson, U. Golla, and M. J. Jecinovic (2001b), Effect of fine-scale microstructure in titanohematite on the acquisition and stability of natural remanent magnetization in granulite facies metamorphic rocks, southwest Sweden: Implications for crustal magnetism, J. Geophys. Res., 106, 30,523-30,546, doi:10.1029/ 2001JB000180.

McEnroe, S. A., R. J. Harrison, P. Robinson, and F. Langenhorst (2002), Nanoscalehaematite-ilmenite lamellae in massive ilmenite rock: An example of 'lamellar magnetism' with implications for planetary magnetic anomalies, Geophys. J. Int., 151, 890-912, doi:10.1046/j.1365246X.2002.01813.x.

McEnroe, S. A., F. Langenhorst, P. Robinson, G. D. Bromiley, and C. S. J Shaw (2004), What is magnetic in the lower crust?, Earth Planet. Sci. Lett., 226, 175-192, doi:10.1016/j.eps1.2004.07.020.

McEnroe, S. A., R. J. Harrison, P. Robinson, F. Langenhorst, C. Frandsen, M. P. Terry, and T. Boffa Ballaran (2007), Magnetization of exsolution intergrowths of hematite and ilmenite: Mineral chemistry, phase relations, and magnetic properties of hemo-ilmenite ores with micro- to nanometerscale lamellae from Allard Lake, Quebec, J. Geophys. Res., 112, B10103, doi:10.1029/2007JB004973.

McEnroe, S. A., L. L. Brown, and P. Robinson (2009), Remanent and induced magnetic anomalies over a layered intrusion: Effects from crystal fractionation and magma recharge, Tectonophysics, 478, 119-134, doi:10.1016/j.tecto.2008.11.021.
Pechersky, D. M. (2007), The geomagnetic field at the Pleozoic/Mesozoic and Mesozoic/Cenozoic boundaries and lower mantle plumes, Phys. Solid Earth, 43, 844-854, doi:10.1134/S1069351307100072.

Peters, C., and M. J. Dekkers (2003), Selected room temperature magnetic parameters as a function of mineralogy, concentration and grain size, Phys. Solid Earth, 28, 659-694.

Qi, X., J. C. Grimmer, and Z. Xu (2009), Ultrahigh-pressure texture inheritance during retrogression: Evidence from magnetofabrics in eclogites and ultramafic rocks (Chinese Continental Scientific Drilling project), Tectonophysics, 475, 267-278, doi:10.1016/j.tecto.2008.09.015.

$\mathrm{Wu}, \mathrm{Q} .(2001)$, Study on the lithosphere structure along the middle part of Tanlu fault zone, Ph.D thesis, Univ. of China, Wuhan.

Renne, P. R., G. R. Scott, J. M. G. Glen, and J. M. Feinberg (2002), Oriented inclusions of magnetite in clinopyroxene: Source of stable remanent magnetization in gabbros of the Messum Complex, Namibia, Geochem. Geophys. Geosyst., 3(12), 1079, doi:10.1029/2002GC000319.

Robinson, P., R. Harrison, S. McEnroe, and R. Hargraves (2002), Lamellar magnetism in the hematite-ilmenite series as an explanation for strong remanent magnetization, Nature, 418, 517-520, doi:10.1038/ nature00942.

Robinson, P., R. Harrison, S. McEnroe, and R. Hargraves (2004), Nature and origin of lamellar magnetism in the hematite-ilmenite series, Am. Mineral., 89, 725-747.

Robinson, P., F. Heidelbach, A. M. Hirt, S. A. McEnroe, and L. L. Brown (2006), Crystallographic-magnetic correlations in single-crystal haemoilmenite: New evidence for lamellarmagnetism, Geophys. J. Int., 165, 17-31, doi:10.1111/j.1365-246X.2006.02849.x.

Santoyo-Salazar, J., M. A. Castellanos-Roman, and L. Beatriz Gómez (2007), Structural and magnetic domain characterization of magnetite nanoparticles, Mater. Sci. Eng., 27, 1317-1320, doi:10.1016/j.msec. 2006.07.027.

Shebanova, O. N., and P. Lazor (2003), Raman spectroscopic study of magnetite $\left(\mathrm{FeFe}_{2} \mathrm{O}_{4}\right)$ : A new assignment for the vibrational spectrum, J. Solid State Chem., 174, 424-430, doi:10.1016/S0022-4596(03)00294-9.

Shive, P. N., B. J. Blakely, B. R. Frost, and D. M. Fountain (1992) Magnetic properties of the lower continental crust, in Continental Lower Crust, edited by D. M. Fountain, R. Arculus, and R. W. Kay, pp. 145-177, Elsevier, Amsterdam.

Strada, E., F. M. Talarico, and F. Florindo (2006), Magnetic petrology of variably retrogressed eclogites and amphibolites: A case study from the Hercynian basement of northern Sardinia (Italy), J. Geophys. Res., 111, B12S26, doi:10.1029/2006JB004574.

Tarduno, J. A., R. D. Cottrell, and A. V. Smirnov (2001), High geomagnetic intensity during the Mid-Creataceous from Thellier analysis of single plagioclase crystals, Science, 291, 1779-1783, doi:10.1126/ science. 1057519

Verwey, E. J., P. W. Haayman, and F. C. Romeijn (1947), Physical properties and cation arrangement of oxides with spinel structure, J. Chem. Phys., 15, 181-189, doi:10.1063/1.1746466.

Wang, A., K. E. Kuebler, B. L. Jolliff, and L. A. Haskin (2004), Raman spectroscopy of Fe-Ti-Cr-oxides, case study: Martian meteorite EETA79001, Am. Mineral., 89, 665-680.

Wang, Q., L. Burlini, D. Mainprice, and Z. Xu (2009), Geochemistry, petrofabrics and seismic properties of eclogites from the Chinese Continental Scientific Drilling boreholes in the Sulu UHP terrane, eastern China, Tectonophysics, 475, 251-266, doi:10.1016/j.tecto.2008.09.027.

Wasilewski, P., and M. A. Mayhew (1992), The Moho as a magnetic boundary revisited, Geophys. Res. Lett., 19, 2259-2262, doi:10.1029/ 92GL01997.

Yang, W. (2009), The crust and upper mantle of the Sulu UHPM belt, Tectonophysics, 475, 226-234, doi:10.1016/j.tecto.2009.02.048.

Xu, H., Z. M. Jin, R. Mason, and X. Ju (2009), Magnetic susceptibility of ultrahigh-pressure eclogite: The role of retrogression, Tectonophysics, 475, 279-290, doi:10.1016/j.tecto.2009.03.020.

Xu, Z., Q. Wang, Z. Tang, and F. Chen (2009), Fabric kinematics of the ultrahigh-pressure metamorphic rocks from the main borehole of the Chinese Continental Scientific Drilling Project: Implications for continental subduction and exhumation, Tectonophysics, 475, 235-250, doi:10.1016/j.tecto.2009.02.041.

Zeng, L., F. Liang, Z. Chen, F. Liu, and Z. Xu (2009), Metamorphic garnet pyroxenite from the 540-600 m main borehole of the Chinese Continental Scientific Drilling (CCSD) project, Tectonophysics, 475, 396-412, doi:10.1016/j.tecto.2009.02.043.

Zhang, Z.-M., Y.-L. Xiao, J. Hoefs, J. G. Liou, and K. Simon (2006), Ultrahigh pressure metamorphic rocks from the Chinese Continental Scientific Drilling Project: I. Petrology and geochemistry of the main hole (0-2050 m), Contrib. Mineral. Petrol., 152, 421-441, doi:10.1007/ s00410-006-0120-5. 